\title{
Correction to: Dianne Otto (ed): Queering International Law: Possibilities, Alliances, Complicities, Risks
}

\section{Routledge, 2017, ISBN: 978-1-138-28991-8}

\section{Emily Jones ${ }^{1}$}

Published online: 20 June 2018

(C) Springer Nature B.V. 2018

\section{Correction to: Fem Leg Stud https://doi.org/10.1007/s10691-018-9374-3}

In the original publication of the article, the name "Tamsin Phillipa Paige" has been incorrectly cited throughout the article as "Tasmin Phillipa Page". The correct name should read as Tamsin Phillipa Paige.

The original article can be found online at https://doi.org/10.1007/s10691-018-9374-3.

Emily Jones

e.jones@essex.ac.uk

1 School of Law, University of Essex, Wivenhoe Park, Colchester CO4 3SQ, UK 